\title{
THE INFLUENCE OF PRODUCT QUALITY, PRICE PERCEPTION, AND BRAND IMAGE ON FURNITURE PURCHASE AT PT. JATI CITY FURINDO JEPARA
}

\author{
Ari Hidayat ${ }^{1}$ \\ Dian Triyani ${ }^{2}$ \\ Lulus Prapti ${ }^{3}$
}

Faculty of Economics, Semarang University (USM)

\begin{abstract}
There are some factors that can influence the success and failure of furniture companies include product quality, price perception, and brand image that can have an impact on consumer purchasing decisions. The aimed of study to analyze the influence of product quality, price perception, and brand image on purchasing decisions.

The object of this study is PT Kota Jati Furindo Jeparam, this companies is one of the companies engaged in the furniture trade located on Jl. Jepara-Bangsri No.Km 6.5 hamlet 1, Suwawal, Mlonggo, Jepara, Central Java. The samples of this study are consumers who bought furniture at PT Kota Jati Furindo Jepara. The reasearcher use linear regression to analyze this study.

The results showed that product quality, price perception and brand image had a positive and significant effect on purchasing decisions. Better product quality, price perception, and brand image of furniture will further enhance consumer purchasing decisions on furniture at PT Kota Jati Furnindo Jepara.
\end{abstract}

Keywords: product quality, price perception, brand image, purchasing decisions

\section{INTRODUCTION}

In the current era of globalization, business competitions between companies are getting very though, in terms of the level of competition between companies and the marketing strategies that were used. They have to determine the right strategy so they can compete. It makes each company trying to increase market share and get new customers to buy their product as to create high purchasing decisions from the company's products.

\footnotetext{
${ }^{1}$ arihidayat@gmail.com; Faculty of Economics, Semarang University (USM)

2 diantriyani@usm.ac.id; Faculty of Economics, Semarang University (USM)

3lulusprapti@usm.ac.id; Faculty of Economics, Semarang University (USM)
} 
The economic development in the business world today grows many new companies from various sectors, especially industries, one of which is triggered by the vast market share 
which is possible to be achieved by the company. It makes public as consumers have many choices to determine their desired alternative products and services which is seen from the large number of brands, products, and services and competitive prices in the market. One of the industries that is currently grow fast in Indonesia is the furniture industry.

Furniture industry is an industry that processes semi-finished materials or raw materials such as wood, rattan, and other natural materials into finished products called furniture so that they have higher utility, benefits and added value. Furniture is a piece of equipment or house interiors that is used for daily life such as tables, chairs, and cabinets that are formed by wood craftsmen or called carpentry.

In Indonesia, there are many carpentry in Central Java, especially in Jepara. Jepara is already known in Indonesia and even abroad as a sector which create unique furniture which is difficult to be imitated in other regions and even other countries. Over time, Jepara became the center of furniture industry in Central Java, which produces high quality wood and it spread throughout Indonesia.

In Jepara, there are many furniture companies, both with legal entities and individuals because some people believe by produce furniture can give them advantage and also can increase their economic level. They also have to be encouraged to grow continuously from time to time so that they stay unique so it will not disappear for the progress of the region itself or Indonesia.

The more a company develops, the more competitors appear. There are many things that can affect the success and failure of furniture companies, they are include product quality, price perception, and brand image. These factors can impact on consumer purchasing decisions. Intense competition forces the companies to become smarter in determining a good marketing strategy. Companies have to improve the quality of products that will be produced later so that consumers get what they want.

Product quality according to Kotler and Armstrong (2007) is the ability of a product to perform its functions, its capabilities include durability, reliability, accuracy produced, ease of operation and repair, and other valuable attributes on the product in general. It means that the company should be able to provide the uniqueness and superiority of its products through performance, features, reliability, suitability, perceived quality, and ability to serve as good quality products will make marketing a product easier because good products have a special position in consumers. 
The level of consumer awareness on a product can be increased through several efforts, by fulfill consumer needs, consumer desires, and speed of delivery to consumers. Because good quality products will make the consumer remember the product so the marketing of a product is easier. In addition, to improve good quality of products, the company should calculate the selling price in accordance with the product quality and which is not burden the consumers. So consumers can get products at the desired price.

\section{THEORETICAL BACKGROUND}

Price according to Kotler and Armstrong (2008) is the amount of money exchanged for a product or service. Or in other words, price is the amount of value exchanged by consumers in order to get a benefit from goods or services. Appropriate prices in the market are able to attract consumers' interest in the process of making purchasing decisions. Price is a consideration for consumers, because some consumers see the price of the value of the product or service.

Another important factor is that a company must increase is the popularity of its brand through advertisements or promotions so consumers will know and remember the brand. Brand image can also be a strong magnet in the competition to compete for and win the consumer market. Image as a set of beliefs, ideas and impressions that a person has of an object. Brand image according to Kotler and Keller (2009) is the perception and belief held by consumers, as reflected by the association embedded in consumers' memories.

Purchasing decision is a stage in the decision making process of consumers to buy an item or service. Therefore the furniture company must plan strategies to attract consumer interest. As is the case with a furniture company in Jepara, PT Kota Jati Furindo, located on St. JeparaBangsri No.km 6.5 hamlet 1, Suwawal, Mlonggo, Jepara, Central Java 59452, Indonesia.

PT Kota Jati Furindo Jepara presents a diverse collection of furniture designed with unique pattern and styles to fulfill market demand. There are some collections which available at this company such as various types of chairs, cabinets, beds, and tables. All teak furniture has gone through a production process in accordance with export quality standards, starting from the selection of high quality materials, to the time of the packaging process. All of these steps are to ensure product quality and improve consumer purchasing decisions. However, due to competition from several similar companies, the impact on furniture sales has declined from year to year. 
PT. Kota Jati Furindo Jepara experienced a significant decline in 2016 to 2018. In 2016 sales fell to 576 units from 659 units in the previous year. Then in 2017 sales decreased to 529 units and in the following year 2018 there was a significant decline to 497 units. Therefore, due to those sales decrease, it is assumed that the quality of the product, price, and brand image of the company causes the decrease of consumer interest in purchasing decisions on the company. With this case shows that there are problems faced by the company.

It is supported by a study by Fure, et al (2015) which show that brand image, and product quality partially have a significant effect on purchasing decisions, but price does not significantly influence purchasing decisions on J.Co Manado Town Square Products. Another study conducted by Yustiawan (2016) showed that product quality, price and brand image variables had a positive influence on purchasing decisions on the Honda Vario in MPM Sidoarjo. While based on the value of the partial determination coefficient the product quality variable is the variable that has the dominant influence on purchasing decisions. Research Rawung, et al (2015) stated that the brand and price have a positive and significant effect on purchasing decision variables, while product quality does not affect the purchasing decision variables on Suzuki motorcycle PT. Sinar Galesong Pratama Manado. A study conducted by Prasastiningtyas (2016) shows that brand image, product quality, and price have a positive effect on cellular card purchasing decisions.

\section{Logical Relationship between Variables and Hypothesis Formulation}

\section{The Relationship of Product Quality on Purchasing Decisions}

Product Quality is closely related to purchasing decisions, where product quality is one aspect of consumer consideration in purchasing decisions. Good quality will lead to customer satisfaction which in turn will make consumers become loyal to the product.

This is supported by research conducted by Prasastiningtyas (2016) that product quality has a positive effect on purchasing decisions. And research conducted by Amrullah and Agustin (2016) that product quality has a significant positive effect on purchasing decisions. Then the hypothesis is as follows:

\section{H1: Product quality has a positive influence on purchasing decisions}

\section{The Relationship of Price Perception on Purchasing Decisions}

Price is one of the main factors that influence purchasing decisions made by consumers. The selling price is essentially an offer to consumers. If the consumer accepts the price, the product would sold out, and contrary. 
It is supported by research conducted by Yustiawan (2016) that price has a positive effect on purchasing decisions. And research conducted by Prasastiningtyas (2016) that Price has a positive effect on purchasing decisions. Then the hypothesis is as follows:

\section{H2: Price perception has a positive influence on purchasing decisions}

\section{The Relationship of Brand Image on Purchasing Decisions}

Consumer with a positive image of a product is more likely to make a purchase, therefore the main use of advertising is to build a positive image of a product. The better the image of a brand, the higher the consumer's decision to make a purchase.

This is also supported by research conducted by Rawung, et al (2015), that brand image has a positive effect on purchasing decisions. And research conducted by Yustiawan (2016) that brand image has significant and positive influence on purchasing decisions. Then the hypothesis is as follows:

\section{H3: Brand image has a positive influence on purchasing decisions}

\section{METHOD, DATA AND ANALYSIS}

This research took the object of research at PT Kota Jati Furindo Jepara, one of the companies engaged in the furniture trade. PT Kota Jati Furindo Jepara is a furniture company located on Jl. Jepara-Bangsri No.Km 6.5 hamlet 1, Suwawal, Mlonggo, Jepara Regency, Central Java. The reason for choosing the object is because the company is still relatively new. While the samples in this study are consumers who have purchased furniture at PT Kota Jati Furindo Jepara.

\section{Analysis}

In this study, to address the existing problems will be used multiple linear regression analysis (MultipleRegresion). In the multiple linear regressions analysis the independent variable (X) which calculated the effect on the dependent variable $(\mathrm{Y})$ the number is more than one. In this study, the independent variables are Product Quality $\left(\mathrm{X}_{1}\right)$, Price Perception $\left(\mathrm{X}_{2}\right)$, Brand image $\left(\mathrm{X}_{3}\right)$, the dependent variable is the Purchasing Decision (Y). 


\section{Research result}

\section{Description of Product Quality Variables}

Respondents to each statement in the product quality variable are as follows:

\section{Results of Respondents' Responses Regarding Product Quality Variables}

Respondent Response Results Regarding Product Quality Variables

\begin{tabular}{|c|c|c|c|c|c|c|c|c|c|}
\hline \multirow{2}{*}{ No } & \multirow{2}{*}{ Attributes Statement } & \multirow{2}{*}{ Frequency } & \multicolumn{5}{|c|}{ Score Score } & \multirow{2}{*}{$\begin{array}{c}\text { Total } \\
\text { Number }\end{array}$} & \multirow{2}{*}{ of } \\
\hline & & & STS & TS & CS & $\mathrm{S}$ & SS & & \\
\hline \multirow{2}{*}{1} & \multirow{2}{*}{$\begin{array}{l}\text { Furniture at PT Kota Jati } \\
\text { Furindo has reliable product } \\
\text { quality. }\end{array}$} & Frequency & 1 & 2 & 17 & 59 & 17 & 96 & \multirow{2}{*}{3.93} \\
\hline & & $\mathrm{F} \times \mathrm{s}$ & 1 & 4 & 51 & 236 & 85 & 377 & \\
\hline \multirow{2}{*}{2} & \multirow{2}{*}{$\begin{array}{l}\text { Furniture at } 5 \text { PT Kota Jati } \\
\text { Furindo has various types and } \\
\text { shapes. }\end{array}$} & Frequency & 1 & 5 & 32 & 49 & 9 & 96 & \multirow{2}{*}{3.62} \\
\hline & & Fxs & 1 & 10 & 96 & 196 & 45 & 348 & \\
\hline \multirow{2}{*}{3} & \multirow{2}{*}{$\begin{array}{l}\text { PT Kota Jati Furindo is able } \\
\text { to satisfy consumers through } \\
\text { the service of its products. }\end{array}$} & Frequency & 1 & 11 & 53 & 23 & 8 & 96 & \multirow{2}{*}{3.27} \\
\hline & & Fxs & 1 & 22 & 159 & 92 & 40 & 314 & \\
\hline \multirow{2}{*}{4} & \multirow{2}{*}{$\begin{array}{l}\text { I believe in the quality of } \\
\text { furniture in PT Kota Jati } \\
\text { Furindo. }\end{array}$} & Frequency & 2 & 15 & 48 & 26 & 5 & 96 & \multirow{2}{*}{3.18} \\
\hline & & F xs & 2 & 30 & 144 & 104 & 25 & 305 & \\
\hline \multicolumn{9}{|c|}{ Total } & 3.41 \\
\hline
\end{tabular}

Source: primary data processed 2019

From the table it is known that respondents' answers regarding product quality variables are with an average number of 3.41 including in the category "Agree or Good" which means the product quality variable with indicators: The furnitures at PT. Kota Jati Furindo Jepara has reliable product quality, The furnitures at PT. Kota Jati Furindo Jepara has various types and shapes, PT. Kota Jati Furindo Jepara is able to satisfy consumers through its product service, and I believe in the quality of furniture at PT. Kota Jati Furindo Jepara.

However, of the four (4) indicators above there are included in the category of "Neutral or Quite Agree" namely the indicator of PT Kota Jati Furindo able to satisfy consumers through service products with an average score of 3.27 and an indicator "I believe in the 
quality of furniture at PT Kota Jati Furindo" with an average score of 3.18. Thus it can be seen that consumers / customers are not fully satisfied with the service of furniture products and do not fully trust the quality of furniture PT. Kota Jati Furindo Jepara. Then the company must provide service satisfaction and good quality furniture to consumers again until they are satisfied..

\section{Description of Price Perception Variables}

The responses of the respondents to each statement in the price variable are as follows:

The Results of Respondents' Responses Regarding Price Perception Variable

\begin{tabular}{|c|c|c|c|c|c|c|c|c|c|}
\hline \multirow{2}{*}{ No. } & \multirow{2}{*}{ Attribute statement } & \multirow{2}{*}{$\begin{array}{l}\text { Frequency } \\
\text { score }\end{array}$} & \multicolumn{5}{|c|}{ Score } & \multirow{2}{*}{ Number } & \multirow{2}{*}{ Averageof } \\
\hline & & & STS & TS & CS & $\mathrm{S}$ & SS & & \\
\hline \multirow{2}{*}{1} & \multirow{2}{*}{$\begin{array}{l}\text { The Furniture Price at PT. } \\
\text { Kota Jati Furindo is } \\
\text { affordable for consumers. }\end{array}$} & Frequency & 4 & 4 & 38 & 41 & 4 & 96 & \multirow{2}{*}{3,54} \\
\hline & & F xs & 4 & 8 & 144 & 164 & 20 & 340 & \\
\hline \multirow[b]{2}{*}{2} & \multirow{2}{*}{$\begin{array}{l}\text { The price of furniture from } \\
\text { PT Kota Jati Furindo is } \\
\text { comparable to the quality of } \\
\text { the products obtained by } \\
\text { consumers. }\end{array}$} & Frequency & 0 & 11 & 35 & 48 & 2 & 96 & \multirow[b]{2}{*}{3.43} \\
\hline & & F xs & 0 & 22 & 105 & 192 & 10 & 329 & \\
\hline \multirow{2}{*}{3} & \multirow{2}{*}{$\begin{array}{l}\text { Furniture prices of PT Kota } \\
\text { Jati Furindo are able to } \\
\text { compete with other } \\
\text { companies. }\end{array}$} & Frequency & 1 & 10 & 40 & 42 & 3 & 96 & \multirow{2}{*}{3.37} \\
\hline & & F xs & 1 & 20 & 120 & 168 & 15 & 324 & \\
\hline \multirow{2}{*}{4} & \multirow{2}{*}{$\begin{array}{l}\text { Furniture prices of PT Kota } \\
\text { Jati Furindo are able to adjust } \\
\text { to the needs of consumers. }\end{array}$} & Frequency & 0 & 7 & 42 & 42 & 5 & 96 & \multirow{2}{*}{3.47} \\
\hline & & F xs & 0 & 14 & 126 & 168 & 25 & 333 & \\
\hline \multicolumn{9}{|c|}{ Total } & 3.45 \\
\hline
\end{tabular}

Source: primary data processed 2019

From this table, it is known that the respondent's answer regarding the Price Perception variable is an average of 3.45 included in the category, "Agree or Good" which means the price perception variable with indicators: furniture prices at PT. Kota Jati Furindo Jepara affordable for consumers, furniture prices PT. Kota Jati Furindo Jepara is comparable to the quality of products obtained by consumers, furniture prices of PT. Kota Jati Furindo Jepara is 
able to compete with other companies, and furniture prices of PT. Kota Jati Furindo Jepara is able to adjust to the needs of consumers.

However, of the four (4) indicators above there are included in the category of "Neutral or Quite Agree" that is the indicator of furniture prices of PT Kota Jati Furindo Jepara able to compete with other companies with an average score of 3.27. Thus it can be seen that the price of furniture at PT. Kota Jati Furindo Jepara has not been fully able to compete with other companies with the possibility that the furniture prices are relatively more expensive than other companies. Then the company must evaluate the price of furniture and even make changes in the price of furniture again until at least assessed by respondents satisfied / good.

\section{Description of Brand Image Variables}

The response of the respondents to each statement in the brand image variable are as follows:

TheResults of Respondents' Responses Regarding Brand Image Variable

\begin{tabular}{|c|c|c|c|c|c|c|c|c|c|}
\hline \multirow{2}{*}{ No. } & \multirow{2}{*}{ Attributes ofIndicators } & \multirow{2}{*}{ Frequency } & \multicolumn{5}{|c|}{ Score } & \multirow{2}{*}{$\begin{array}{c}\text { Total } \\
\text { Number }\end{array}$} & \multirow{2}{*}{ of } \\
\hline & & & STS & TS & CS & $S$ & SS & & \\
\hline \multirow{2}{*}{1} & \multirow{2}{*}{$\begin{array}{l}\text { PT Kota Jati Furindo's furniture } \\
\text { brand image is superior to other } \\
\text { companies. }\end{array}$} & Frequency & 3 & 10 & 28 & 42 & 13 & 96 & \multirow{2}{*}{3.54} \\
\hline & & F xs & 3 & 20 & 84 & 168 & 65 & 340 & \\
\hline \multirow{2}{*}{2} & \multirow{2}{*}{$\begin{array}{l}\text { PT Kota Jati Furindo prioritizes } \\
\text { Prestige (maintain appearance) } \\
\text { company. }\end{array}$} & Frequency & 1 & 10 & 40 & 42 & 3 & 96 & \multirow{2}{*}{3.37} \\
\hline & & F xs & 1 & 20 & 120 & 168 & 15 & 324 & \\
\hline \multirow{2}{*}{3} & \multirow{2}{*}{$\begin{array}{l}\text { The furniture brand image of PT } \\
\text { Kota Jati Furindo can be trusted } \\
\text { by consumers. }\end{array}$} & Frequency & 5 & 14 & 27 & 42 & 8 & 96 & \multirow{2}{*}{3.35} \\
\hline & & F xs & 5 & 28 & 81 & 168 & 40 & 322 & \\
\hline \multicolumn{9}{|c|}{ Total } & 3.42 \\
\hline
\end{tabular}

Source: primary data processed 2019

From this table it is known that the respondents' answers regarding the Brand Image variable are an average of 3.42 included in the category "Agree or Good" meaning the brand image variable with indicators: furniture brand image of PT. Kota Jati Furindo Jepara is superior to other companies, PT. Kota Jati Furindo Jepara prioritizes the prestige of the company, and the furniture brand image of PT. Kota Jati Furindo Jepara can be trusted by consumers. However, of the four (4) indicators above there are included in the category of "Neutral or Quite Agree" namely the indicator of PT. Kota Jati Furindo Jepara prioritizes the company's 
prestige (maintaining appearance) with an average score of 3.37 and an indicator of the furniture brand image of PT. Kota Jati Furindo Jepara can be trusted by consumers with an average score of 3.35. Thus it can be seen that consumers / customers are not yet fully interested in the prestige (appearance) of furniture products and have not fully trusted the furniture brand image of PT. Kota Jati Furindo Jepara. Then the company must attract consumer interest and trust in the company's image again until at least judged by respondents satisfied / good.

\section{Description of Purchase Decision Variables}

The responses of the respondents to each statement in the purchase decision variable are as follows:

The Results of Respondents Response Variable Purchase Decision

\begin{tabular}{|c|c|c|c|c|c|c|c|c|c|}
\hline \multirow{2}{*}{ No. } & \multirow{2}{*}{ Attribute statement } & \multirow{2}{*}{$\begin{array}{l}\text { Frequency } \\
\text { score }\end{array}$} & \multicolumn{5}{|c|}{ Score } & \multirow{2}{*}{ Number } & \multirow{2}{*}{$\begin{array}{c}\text { Average } \\
\text { of }\end{array}$} \\
\hline & & & STS & TS & CS & S & SS & & \\
\hline \multirow{2}{*}{1} & \multirow{2}{*}{$\begin{array}{l}\text { I decided to buy furniture } \\
\text { because I am sure about PT } \\
\text { Kota Jati's products Furindo } \\
\text { Jepara }\end{array}$} & Frequency & 2 & 7 & 45 & 36 & 6 & 96 & \multirow{2}{*}{3.39} \\
\hline & & F xs & 2 & 14 & 135 & 144 & 30 & 325 & \\
\hline \multirow{2}{*}{2} & \multirow{2}{*}{$\begin{array}{l}\text { I decided to buy furniture } \\
\text { products at PT Kota Jati } \\
\text { Furindo Jepara out of habit }\end{array}$} & Frequency & 2 & 7 & 38 & 45 & 4 & 96 & \multirow{2}{*}{3.44} \\
\hline & & F xs & 2 & 14 & 114 & 180 & 20 & 330 & \\
\hline \multirow[b]{2}{*}{3} & \multirow{2}{*}{$\begin{array}{l}\text { I decided to be back again at } \\
\text { PT Kota Jati Furindo Jepara if } \\
\text { I wanted to buy furniture } \\
\text { again }\end{array}$} & Frequency & 0 & 8 & 40 & 44 & 4 & 96 & \multirow[b]{2}{*}{3.46} \\
\hline & & F xs & 0 & 16 & 120 & 176 & 20 & 332 & \\
\hline \multirow[b]{2}{*}{4} & \multirow{2}{*}{$\begin{array}{l}\text { I decided to buy furniture at } \\
\text { PT Kota Jati Furindo Jepara } \\
\text { because of recommendations } \\
\text { from others }\end{array}$} & Frequency & 6 & 10 & 42 & 29 & 9 & 96 & \multirow{2}{*}{3.26} \\
\hline & & F xs & 6 & 20 & 126 & 116 & 45 & 313 & \\
\hline \multicolumn{9}{|c|}{ Total } & 3.39 \\
\hline
\end{tabular}

Source: primary data processed 2019

From this table, it is known that the ans

wers of the respondens regarding the purchase decision variable with an average amount of 3.39 and in the category of "Neutral or Quite Agree" which means the purchase decision variable with indicators: "I decided to buy furniture because I am sure about PT Kota Jati's 
products Furindo Jepara", "I decided to buy furniture products at PT Kota Jati Furindo Jepara out of habit", "I decided to be back again at PT Kota Jati Furindo Jepara if I wanted to buy furniture again", "I decided to buy furniture at PT Kota Jati Furindo Jepara because of recommendations from others".

This can be seen in the indicator "I decided to buy furniture at PT Kota Jati Furindo Jepara because of recommendations from others" who had the lowest average score of 3.26. Thus it can be seen that consumers are not fully satisfied with the furniture products of PT. Kota Jati Furindo Jepara so consumers don't give recommendations to others. Then the company must provide satisfaction to consumers again until at least judged by respondents satisfied / good.

Multiple linear regression analysis aims to determine the effect of independent and dependent variables. Regression test results are as follows:

Table Coefficient Regression

Coefficients $^{\mathrm{a}}$

\begin{tabular}{|l|r|r|r|r|r|r|r|}
\hline \multirow{2}{*}{ Model } & \multicolumn{2}{|c|}{$\begin{array}{c}\text { Unstandardized } \\
\text { Coefficients }\end{array}$} & $\begin{array}{c}\text { Coefficients } \\
\text { Standardize } \\
\mathrm{d}\end{array}$ & \multicolumn{2}{|c|}{$\mathrm{T}$} & \multirow{2}{*}{ Sig. } & \multicolumn{2}{c|}{$\begin{array}{c}\text { Collinearity } \\
\text { Statistics }\end{array}$} \\
\cline { 2 - 4 } & $\mathrm{B}$ & Std. Error & Beta & & & $\begin{array}{c}\text { Toleranc } \\
\mathrm{e}\end{array}$ & VIF \\
\hline (Constant) & $-1,119$ & 1,373 & & -815 &, 417 & & \\
\hline Quality Products &, 140 &, 078 &, 126 & 1,792, &, 046 &, 879 & 1.138 \\
Perception of Price &, 756 &, 081 &, 658 & 9.332, &, 000 &, 873 & 1,145 \\
Brand &, 220 &, 090 &, 171 & 2,442, &, 017 &, 888 & 1,126 \\
\hline
\end{tabular}

a. Dependent Variable: Purchasing Decision

Source: Primary data processed 2019

The regression coefficient that was used is standardized coefficients. Based on these values a linear equation can be made as follows:

$$
Y=0.126 X 1+0.658 X 2+0.171 X 3
$$

The multiple linear regression equation can be interpreted that:

1. The product quality regression coefficient of 0.126 . This shows the coefficient is positive, meaning that better the quality of the product will make the consumers decide to purchase faster 
2. Price perception regression coefficient of 0.658 . This shows the coefficient is positive, meaning that that better price perception will make the consumers decide to purchase faster.

3. Brand image regression coefficient of 0.171 . This shows the coefficient is positive, meaning that that better the brand image, will make the consumers decide to purchase faster.

\section{RESULT AND DISCUSSION}

\section{The Influence of Product Quality on Purchasing Decisions}

The effect of the first results states that product quality has a positive and significant effect on purchasing decisions, which means that better the quality of the product will make the consumers decide to purchase faster. The quality of furniture products of PT. Kota Jati Furindo Jepara has long-lasting or long-term durability. On the other hand the quality of furniture products of PT. Kota Jati Furindo Jepara has a variety of specifications that are desired by consumers and have good product appearance. So consumers can decide to buy the furniture.

The results of this study are in line with research conducted by Amrullah and Agustin (2016) which states that product quality has a significant positive effect on purchasing decisions.

\section{The Influence of Price Perception on Purchasing Decisions.}

The effect of the second result states that price perception has a positive and significant effect on purchasing decisions, which means that better price perception will make the consumers decide to purchase faster. Furniture at PT. Kota Jati Furindo Jepara has affordability, the price of furniture in accordance with the quality of the products offered, the competitiveness of furniture prices has an advantage with other brands, and the price of furniture can attract consumers to make purchases.

The results of this study are in line with research conducted by Prasastiningsih (2016) that prices have a positive effect on purchasing decisions.

\section{The Influence of Brand Image on Purchasing Decisions}

The influence of the third result states that brand image has a positive and significant influence on purchasing decisions, which means that better the brand image, will make the consumers decide to purchase faster. Brand image is a very important part of PT. Kota Jati Furindo Jepara. Furniture PT. Kota Jati Furindo Jepara has a brand image that is superior to 
other companies and is more competitive for the prestige of the company and can be trusted by consumers.

These results are in line with research conducted by Yustiawan (2016) that brand image has a significant and positive effect on purchasing decisions.

\section{CONCLUSION}

Based on the results of this study, it can be concluded as follows:

1. From the results of hypothesis testing it is known that the product quality variable has a positive and significant effect on furniture purchase decisions at PT. Kota Jati Furindo Jepara. The better the quality of the products provided by PT. Kota Jati Furindo Jepara, will further enhance furniture purchase decisions.

2. From the results of hypothesis testing it is known that the variable price perception has a positive and significant effect on furniture purchase decisions at PT. Kota Jati Furindo Jepara. The better price perception of furniture products of PT. Kota Jati Furindo Jepara, will further enhance furniture purchase decisions.

3. From the results of hypothesis testing it is known that the brand image variable has a positive and significant effect on furniture purchase decisions at PT. Kota Jati Furindo Jepara. The better the brand image of furniture products of PT. Kota Jati Furindo Jepara, will further enhance furniture purchase decisions.

\section{SUGGESTION}

Based on the conclusions that have been described, the following authors propose several suggestions that might improve progress for PT. Kota Jati Furindo Jepara.

1. For product quality at PT. Kota Jati Furindo Jepara, it is expected to be able to provide better service satisfaction and furniture quality to consumers until at least valued by consumers / satisfied / good customers. For example, providing more maximum service to consumers by displaying higher quality furniture products from materials, manufacturing processes and finished goods.

2. For price perception at PT. Kota Jati Furindo Jepara, it is expected to evaluate furniture prices and even change furniture prices again until at least they are valued by consumers / satisfied / good customers. For example, more balancing the price of furniture with other companies or even more daring to lower prices in order to attract consumers and be able to compete with other companies. 
3. For the brand image of PT. Kota Jati Furindo Jepara, it is expected to be able to attract consumer interest and trust in the company's image until at least it is valued by consumers / satisfied / good customers. For example by giving a positive image to consumers by displaying the qualities and advantages which is offered by the company that are not owned by other companies.

In this study, researchers had limitations in analyzing the factors that influence purchasing decisions on furniture in the Jepara region, they are:

1. The limitations of this study only used 3 independent variables namely product quality, price perception, and brand image.

2. The number of samples used in this study is limited to 96 , thus allowing several aspects of each variable to be unmeasured.

The future study agenda will be carried out: based on the results of the coefficient of determination $58.7 \%$ of the variation in the purchase decision variable can be explained by the independent variables in the form of product quality, price perception, and brand image. While the remaining $41.3 \%$ is explained by other variables not observed, so that this study still lacks the independent variables in explaining the dependent variable. Therefore, it is expected that in subsequent studies, it can add variables that are related to the problems faced in the next studies such as promotion and location, by adding the number of samples so that the results are accurate.

\section{REFERENCES}

Prasastiningtyas, T. R. (2016). pengaruh citra merek, kualitas produk, dan harga terhadap keputusan pembelian kartu seluler. jurnal ilmu dan riset manajemen .

Fure, F., Lapian, J., \& Taroreh, R. (2015). pengaruh brand image, kualitas produk, dan harga terhadap keputusan pembelian konsumen di J.CO manado. jurnal EMBA , 367-377.

Rawung, D. R., Oroh, S. G., \& Sumarauw, J. S. B. (2015). analisis kualitas produk, merek, dan harga terhadap keputusan pembelian sepeda motor suzuki pada PT. Sinar Galesong Pratama Manado. jurnal EMBA, 1298-1308.

Wangean, R. H., \& Mandey, S. L. (2014). analisis citra merek, kualitas produk dan harga pengaruhnya terhadap keputusan pembelian konsumen pada mobil all new kia rio di kota manado. jurnal EMBA , 1715-1725.

Yustiawan, O. (2016). pengaruh kualitas produk, harga, dan citra merek terhadap keputusan pembelian honda vario. jurnal ilmu dan riset manajemen . 
Amrullah, A. R. (2016). pengaruh kualitas produk, harga, dan citra merek terhadap keputusan pembelian honda beat. jurnal ISSN, 2461-0593 .

Daryanto, 2011. Manajemen Pemasaran: Sari Kuliah. Bandung: Satu Nusa.

Dinawan, 2010. Kualitas Produk : Alat Strategi Yang Penting, Free Press. PT Raja Grafindo Persada. Jakarta.

Ghozali, Imam. 2007. Aplikasi Analisis Multivariate dengan Program SPSS, Undip, Semarang.

Ghozali, Imam. 2009. Aplikasi Analisis Multivariate dengan Program SPSS, Undip, Semarang.

Ghozali, Imam. 2012. Aplikasi Analisis Multivariate dengan Program SPSS, Undip, Semarang.

Kotler dan Keller, 2007. Manajemen Pemasaran, Edisi 12, Jilid 1, PT.Indeks, Jakarta

Kotler, Philip dan Armstrong Gary, 2008. Prinsip-prinsip Pemasaran Jilid 1 Edisi 12, Erlangga, Jakarta.

Philip Kotler, 2009, Manajemen Pemasaran, Edisi Milenium, Jilid 2, PT Prenhallindo,Jakarta. Simamora, Bilson. 2004. Riset Pemasaran. Cetakan Pertama. Jakarta: PT.Gramedia Pustaka Utama.

Sitinjak, Tumpal JR \& Sugiarto, 2006. LISREL. Yogyakarta: Graha Ilmu. 